\title{
PENGEMBANGAN SDM RUMAH SAKIT DALAM MENGHADAPI ERA GLOBALISASI DAN PERSAINGAN BEBAS
}

\author{
Muhammad Musyfiq Salami, Putri Nilam Kencana, Muger Apriansyah, \\ Agrasadya, Laila Irawati \\ Universitas Pamulang \\ Email: dosen01896@unpam.ac.id
}

\begin{abstract}
This community service activity aims to socialize HR development strategies and motivate employees of Medika Hospital BSD to become superior HR to face the era of globalization and free competition. The results of this activity are expected to face the era of globalization and free competition in the present, it requires superior human resources who have competencies in their fields so that they are able to carry out their duties and obligations properly and optimally. With this socialization and training can have a positive impact on BSD Medika Hospital in general and employees in particular to be more motivated and develop competence. The method used in this Community Service (PKM) activity is to provide socialization and role play in the context of socializing $H R$ development strategies and motivating employees of Medika Hospital BSD to become superior HR to face the era of globalization and free competition.
\end{abstract}

Keywords: PKM, HR, Hospital, Globalization, Free Competition.

\begin{abstract}
Abstrak
Kegiatan pengabdian kepada masyarakat ini bertujuan untuk mensosialisasikan strategi pengembangan SDM dan memotivasi karyawan RS Medika BSD agar menjadi SDM unggul untuk menghadapi era globalisasi dan persaingan bebas. Hasil kegiatan ini diharapkan dalam menghadapi era globalisasi dan persaingan bebas di masa sekarang ini, diperlukan SDM unggul yang memiliki kompetensi di bidangnya sehingga mampu melaksanakan tugas dan kewajibannya dengan baik dan maksimal. Dengan adanya sosialisasi dan pelatihan ini dapat membawa dampak yang positif kepada RS Medika BSD pada umumnya dan para karyawan pada khususnya agar semakin termotivasi dan mengembangkan kompetensi. Metode yang digunakan dalam kegiatan Pengabdian Kepada Masyarakat (PKM) ini adalah memberikan sosialisasi serta role play dalam konteks mensosialisasikan strategi pengembangan SDM dan memotivasi karyawan RS Medika BSD agar menjadi SDM unggul untuk menghadapi era globalisasi dan persaingan bebas.
\end{abstract}

Kata Kunci: PKM, SDM, Rumah Sakit, Globalisasi, Persaingan Bebas. 


\section{A. PENDAHULUAN}

Pada umumnya setiap organisasi menghendaki sumber daya manusia (SDM). bermutu yaitu SDM yang mampu mengkreasi usaha organisasi yang tidak ada menjadi ada, atau dari kehidupan organisasi biasa menjadi organisasi yang mampu melakukan sesuatu yang lebih tinggi bagi kemajuan organisasi. SDM yang bermutu pada prinsipnya mempunyai kemampuan profesional dan teknikal tertentu yang kehadirannya pada semua lini pekerjaan akan melahirkan banyak keuntungan.

Rumah sakit merupakan fasilitas kesehatan rujukan utama bagi masyarakat yang ingin memperoleh pelayanan kesehatan baik untuk pengobatan maupun untuk pemulihan kesehatannya. Sebagai pusat rujukan kesehatan utama, rumah sakit dituntut mampu memberikan pelayanan yang komprehensif bagi setiap pasiennya. Pelayanan kesehatan yang komprehensif adalah berbagai bentuk pelayanan yang diberikan kepada klien oleh suatu tim multi disiplin sesuai kebutuhan pasien. SDM di rumah sakit menjadi hal penting yang mendukung berkembangnya rumah sakit dan menjadi tolak ukur penting dalam penilaian pengembangan mutu pelayanan di rumah sakit.

Dalam organisasi rumah sakit, upaya untuk menciptakan rumah sakit yang mempunyai citra baik (berkualitas) di mata pelanggannya sangat ditentukan oleh kualitas SDM terstandarisasi yang dimilikinya. SDM terstandarisasi berarti tenaga yang dimiliki oleh organisasi telah mempunyai keterampilan dan pengetahuan yang sesuai dengan bidang tugas yang dikerjakan baik dilihat dari tingkat pendidikan maupun pengalaman yang dimiliki SDM yang bersangkutan.

SDM rumah sakit pada dasarnya telah terspesialisasi secara jelas, karena semua tenaga medis seperti perawat, bidan, dokter, dokter spesialis, farmasi dan lain-lain secara khusus telah mempunyai latar belakang pendidikan sesuai dengan bidang tugas yang mereka kerjakan. Dengan latar belakang pendidikan itulah SDM di organisasi rumah sakit diharapkan mampu menunjang pelayanan rumah sakit yang berkualitas. Sebagai perusahaan pelayanan jasa, rumah sakit menghasilkan produk yang bersifat tidak berwujud atau intangible, maka SDM merupakan unsur yang sangat penting baik dalam produksi maupun penyampaian jasa dalam pelayanan berkualitas di rumah sakit. Berbicara peningkatan mutu di rumah sakit yang berhubungan dengan SDM tentu saja terkait dengan pengembangan kompetensi. Kompetensi pada umumnya dapat dipahami sebagai kombinasi antara pengetahuan (knowledge), keterampilan (skill), dan sikap/perilaku (attitude) seorang karyawan sehingga mampu melaksanakan pekerjaannya.

\section{B. METODE PELAKSANAAN KEGIATAN}

Metode yang digunakan dalam kegiatan Pengabdian Kepada Masyarakat (PKM) ini adalah memberikan sosialisasi serta role play dalam konteks mensosialisasikan strategi pengembangan SDM dan memotivasi karyawan RS Medika BSD agar menjadi SDM unggul untuk menghadapi era globalisasi dan persaingan bebas.

Dalam hal ini RS Medika BSD Tangerang, adalah hendaknya lembaga memfasilitasi karyawan dengan pelatihan (training) secara berkala tentang bagaimana strategi pengembangan SDM dan memotivasi karyawan RS Medika BSD agar menjadi SDM unggul untuk menghadapi era globalisasi dan persaingan bebas sehingga SDM semakin kompeten dalam melaksanakan tugas sesuai dengan jobdesk masing-masing dan memberikan dampak positif bagi kemajuan RS Medika BSD Tangerang.

Adapun tahapan-tahapan yang dilakukan dalam kegiatan ini yaitu: 
1. Tahapan Persiapan

a. Mengunjungi RS Medika BSD untuk mengajukan proposal Pengabdian Kepada Masyarakat (PKM).

b. Pembagian kerja (jobdesk) anggota kelompok PKM.

c. Penyusunan bahan/materi yang akan dibawakan saat kegiatan PKM berlangsung.

2. Tahapan Pelatihan

a. Membawakan materi pelatihan (training) tentang bagaimana strategi pengembangan SDM rumah sakit untuk menghadapi era globalisasi dan persaingan bebas.

b. Role Play, bagaimana cara memotivasi karyawan RS Medika BSD agar menjadi SDM unggul untuk menghadapi era globalisasi dan persaingan bebas.

c. Ice Breaking (games), agar peserta pelatihan (karyawan RS Medika BSD) tidak mengantuk dan tidak bosan dalam mendengarkan paparan materi dari Narasumber.

\section{HASIL DAN PEMBAHASAN}

Di dalam sebuah perusahaan manajemen digunakan sebagai alat untuk mencapai sebuah tujuan yang diinginkan oleh sebuah perusahaan. Dengan adanya manajemen yang baik akan memudahkan terwujudnya tujuan perusahaan. Hal ini disebabkan kerjasama akan terjalin dengan adanya manajemen dan bersifat keterkaitan satu sama lain yang jika ada salah satu unsur di dalam manajemen tersebut maka fungsi manajemen tersebut tidak akan berjalan dengan optimal.

Manajemen adalah ilmu dan seni mengatur proses pemanfaatan sumber daya manusia dan sumber-sumber daya lainnya secara efektif dan efisien untuk mencapai tujuan tertentu (Hasibuan 2017:9). Menurut John Suprihanto (2014) mengemukakan bahwa manajemen juga merupakan pengambilan keputusan (management is decision making). Hal ini dapat dilihat bagaimana seseorang harus melakukan pekerjaan, misalnya pimpinan harus mengambil keputusan untuk melakukan pekerjaan, misalnya pimpinan harus mengambil keputusan untuk menentukan pengembangan produk baru, menentukan pasar sasaran, memperluas usaha, menetukan strategi pemasaran, menerima, atau mengeluarkan karyawan dan berbagai pekerjaan yang lain. Sedangkan menurut Jones \& Goerge dalam John suprihanto (2014) menyatakan bahwa manajemen adalah perencanaan, pengorganisasian, memimpin dan pengendalian sumber daya manusia dan lainnya untuk mencapai tujuan organisasi secara efektif dan efisien.

Manajemen berasal dari kata to manage yang artinya mengatur yang diatur di dalam manajemen itu sendiri ialah unsur yang ada di dalam sebuah menajemen yaitu: man, money, material, machines, method, dan market yang disingkat $6 \mathrm{M}$. Manajemen sumber daya manusia (MSDM) merupakan salah satu aset yang penting oleh karena itu harus dikelola secara cermat dan sejalan dengan kebutuhan organisasi. Menurut Hasibuan (2017:10) manajemen sumber daya manusia adalah ilmu atau seni mengatur hubungan dan peranan tenaga kerja agar efektif dan efisien membantu terwujudnya tujuan perusahaan, karyawan, dan masyarakat. Manajemen sumber daya manusia adalah suatu bidang manajemen yang khusus mempelajari hubungan dan peranan manusia dalam organisasi perusahaan. Unsur manajemen sumber daya manusia adalah manusia yang merupakan tenaga kerja pada perusahaan.

Menurut T. Hani Handoko dalam I Gusti Ketut Purnaya (2016) mendefinisikan manajemen sumber daya manusia sebagai suatu proses perencanaan, pengorganisasian, pengarahan, pengawasan kegiatan-kegiatan pengadaan, pengembangan, pemberian 
kompensasi, pengintegrasian, pemeliharaan, dan pelepasan sumber daya manusia agar tercapai berbagai tujuan individu, organisasi dan masyarakat. Sedangkan menurut Henry Simamora dalam Sri Larasati (Manajemen Sumber Daya Manusia:2018) menyampaikan bahwa manajemen sumber daya manusia (human resources management) adalah pendayagunaan, pengembangan, pengelolaan individu anggota organisasi atau kelompok karyawan.

Berdasarkan pendapat para ahli di atas dapat dilihat bahwa terdapat persamaan antara manajemen dan manajemen sumber daya manusia yang memiliki peranan sangat penting di dalam sebuah perusahaan atau organisasi.

Untuk dapat berkompetisi dalam globalisasi kita harus menerapkan rencana strategis untuk meningkatkan SDM terutama dokter dengan tujuan mengubahnya menjadi faktor kekuatan (strength) kompetitif. Sikap beraliansi dan bersinergi antara dokter dan rumah sakit masih sangat perlu untuk dikembangkan. Dalam menghadapi kompetisi global, para ahli berpendapat, bahwa aliansi, sinergi, kompetisi, dan ko-kreasi adalah kekuatan utama yang juga dapat menjadi kunci keberhasilan dalam menghadapi globalisasi.Selain itu, dalam menghadapi globalisasi, rumah sakit harus siap untuk berbenah diri.

Salah satunya rumah sakit harus dapat mengatasi kelemahan-kelemahan yang menghambat untuk dapat bersaing secara global, dengan cara-cara:

1. Menyempurnakan sistem-sistem di rumah sakit.

2. Menyempurnakan sarana untuk mendukung manusia dan sistem.

3. Melakukan perubahan dalam manajemen rumah sakit

Untuk meningkatkan Daya Saing Rumah Sakit maka diperlukan:

1. Kebijakan pemerintah diarahkan untuk memberdayakan rumah sakit agar mampu mandiri, dengan regulasi dan desentralisasi. Peran pemerintah adalah steering bukan rawing, dengan tugas antara lain memantau dan mengevaluasi standar kualitas pelayanan rumah sakit melalui stakeholder di tingkat provinsi dan Dati II dengan melalui akreditasi.

2. Anggaran pemerintah diprioritaskan bagi rumah sakit yang tidak mampu untuk mandiri dan untuk daerah-daerah Indonesia Bagian Timur.

3. Pengembangan metropolitan dan megapolitan diikuti dengan pengembangan kebijakan yang mengatur rumah sakit di urban dan rural area sebagai pusat pelayanan medik dengan Puskesmas sebagai satelit dan binaannya.
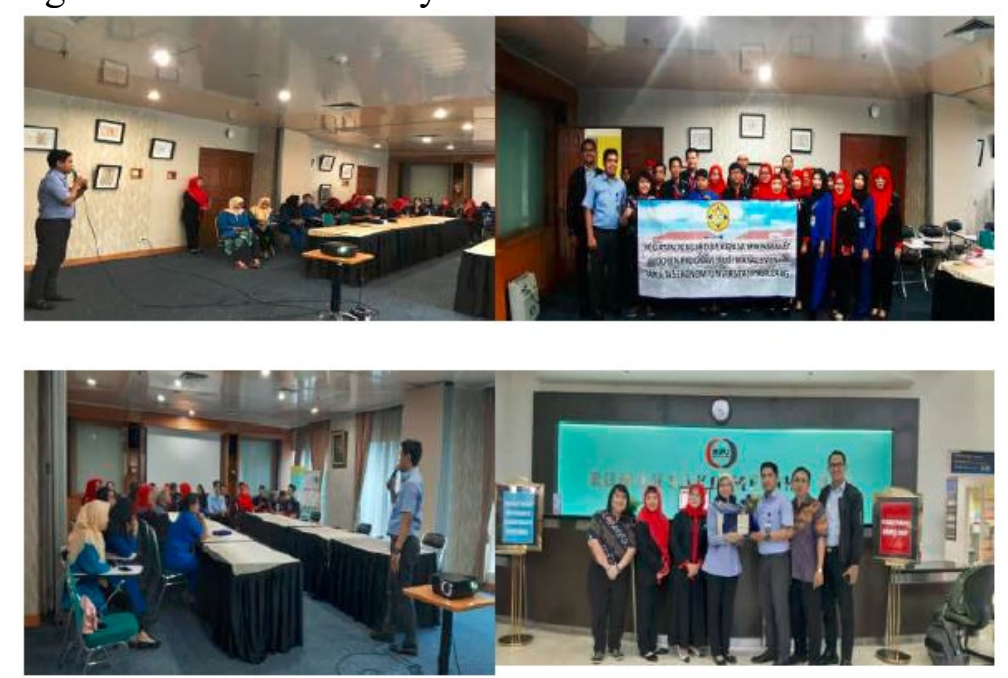

Gambar 1. Foto Kegiatan PKM 


\section{diperlukan:}

Sedangkan dalam rangka Peningkatan Profesionalisme SDM Pelayanan Medik maka

1. Profesionalisme tenaga medik dikembangkan melalui Komite Medik yang ada di rumah sakit, ikatan profesi, fakultas kedokteran dan lembaga perizinan dokter.

2. Profesionalisme tenaga perawat dikembangkan melalui Komite Keperawatan di rumah sakit, fakultas keperawatan, ikatan profesi dan Departemen Kesehatan.

3. Profesionalisme manajer rumah sakit dikembangkan melalui proses pendidikan, pelatihan dan ikatan profesi.

\section{KESIMPULAN DAN SARAN}

\section{Simpulan}

Kegiatan Pengabdian Kepada Masyarakat (PKM) yang telah kami lakukan ini pada dasarnya adalah berkat kerjasama berbagai pihak terkait sehingga kegiatan dapat berjalan dengan baik dan terukur, serta materi yang kami sampaikan dapat bermanfaat bagi karyawan RS Medika BSD Tangerang. Dengan adanya kegiatan Pengabdian Kepada Masyarakat (PKM) ini, diharapkan peserta dapat mengaplikasikan ilmu yang telah mereka peroleh dalam kehidupan sehari-hari. Dan pada akhirnya, ilmu tersebut dapat dirasakan manfaatnya oleh peserta sendiri dan lingkungan di sekitarnya, khususnya lingkungan RS Medika BSD Tangerang.

\section{Saran}

Saran kami terhadap lembaga, dalam hal ini RS Medika BSD Tangerang, adalah hendaknya lembaga memfasilitasi karyawan dengan pelatihan (training) secara berkala tentang bagaimana strategi pengembangan SDM dan memotivasi karyawan RS Medika BSD agar menjadi SDM unggul untuk menghadapi era globalisasi dan persaingan bebas sehingga SDM semakin kompeten dalam melaksanakan tugas sesuai dengan jobdesk masing-masing dan memberikan dampak positif bagi kemajuan RS Medika BSD Tangerang.

\section{DAFTAR PUSTAKA}

Fayol, Henry dalam Hasibuan. (2012). Manajemen Sumber Daya Manusia. Jakarta :Bumi Aksara.

F. Mee, Jhon dalam Hasibuan. (2017). Manajemen Sumber Daya Manusia Edisi Revisi. Jakarta : Bumi Aksara.

Handoko, T. Hani dalam I Gusti Ketut Purnaya. (2016) Manajemen Sumber Daya Manusia. Yogyakarta : CV. Andi Offset.

Hasibuan, Malayu. (2017). Manajemen Sumber Daya Manusia Edisi Revisi. Jakarta : Bumi Aksara

Jones \& Goerge dalam Suprihanto. (2014). Manajemen.Yogyakarta : Gajah Mada University Press. 